\title{
MODERNIZATION HOUSING TERRITORIES \\ OF UKRAINE'S MILITARY CITIES. BACKGROUND AND CONCEPT
}

\section{МОДЕРНІЗАЦІЯ ЖИТЛОВИХ ТЕРИТОРІЙ ВІЙСЬКОВИХ МІСТЕЧОК УКРАЇНИ. ПЕРЕДУМОВИ ТА КОНЦЕПЦІї}

\section{Morozik Alina ${ }^{1}$ \\ Vasylenko Lyudmila ${ }^{2}$}

DOI: http://dx.doi.org/10.30525/978-9934-571-26-8_14

\begin{abstract}
The presented scientific material concerns the modernization of planning decisions and architectural environment military towns of Ukraine. Especially this problem is relevant for small cities, where the military town is a city forming element. The article describes the preconditions and main directions modernization of the architectural environment of the residential part the Ukrainian military towns, outlines the purpose of the study, which is to develop theoretical, methodological and practical approaches to the modernization of the architectural and planning structure of residential areas of military towns. To achieve the goal, the following tasks need to be addressed: the search for and analysis of modern scientific research, in which different approaches are proposed both in designing and practical activities, identifying the principal deficiencies of existing military settlements; development of a methodology for modernizing the planning structure of the residential zone of military towns.

Principles of modernization of the architectural and planning structure residential areas of military towns are the subject of studying modern scientific approaches to the development military towns. At different stages of research, we use the following methods: search monographic and compar-
\end{abstract}

\footnotetext{
${ }^{1}$ Postgraduate Student of the Department of Urban Development, Kyiv National University of Construction and Architecture, Ukraine ORCID 0000-0002-9325-3837

${ }^{2}$ Candidate of Architecture, Associate Professor the Department of Urban Development, Kyiv National University of Construction and Architecture, Ukraine ORCID 0000-0002-3122-0917
} 
ative. The historical and comparative methods are used to study historical types of military territorial objects and determine their development. Analysis, synthesis, methods of synthesis and comparison are used to reveal the characteristics of the architectural and planning and functional structure of military towns. The method of forecasting and experimental designing is used by us in developing project proposals for the modernization planning structure of military towns.

Consequently, the urgent need to address the issues of improving the living environment of servicemen and ensuring their housing are topical issues, as evidenced by state programs aimed at modernizing and developing these facilities. Principles of modernization of military towns are determined in accordance with the existing problems of modern Ukrainian military territorial objects and taking into account the shortcomings of the architectural and urban environment. Analysis of diverse city-planning situations, architectural-planning and spatial decision-making features contributed to the formation principles of modernization, the application of which can be more effective, the combination use of multi-dimensional principles will determine the direction of modernization in each particular case, find rational solutions, methods and techniques modernization. The use of the principles proposed by us allowed us to experimentally verify the results research on specific objects located in Ukrainian small cities. The search for effective ways to modernize the architectural, planning, functional structure, the system cultural and domestic services and the infrastructure of military towns refers to the most urgent tasks of our time.

\section{1. Вступ}

Окреслена нами мета дослідження, яка полягає в розробці теоретичних та практичних підходів модернізації архітектурно-планувальної структури житлової частини військових містечок в малих містах України, потребує рішення наступних задач: дослідити та проаналізувати сучасні наукові розробки та напрямки дослідження в галузі проектування військових територіальних об’ єктів; визначити види військових територіальних об'єктів на певних історичних етапах (таборів, міст-фортець, військових поселень); виявити основні недоліки існуючих військових містечок та окреслити фактори та передумови, що впливають на їх архітектурно-планувальну організацію та функціональне зонування; дослідити практичний вітчизняний та закордон- 


\section{Morozik Alina, Vasylenko Lyudmila}

ний досвід територіальної організації об'єктів; визначити типологічні групи сучасних військових містечок та виявити особливості їх формування; розробити методику модернізації планувальної структури військових містечок; перевірити експериментально виявлені принципи осучаснення.

В досліджені сучасних наукових напрямків вивчення військових містечок використовується пошуковий, монографічний та порівняльний методи. У вивченні історичних видів військових територіальних об'єктів та визначенні їх розвитку використовується пошуковий історичний та порівняльний методи. Для виявлення характеристик планувальної та функціональної структури військових містечок застосовані аналіз, синтез, методи узагальнення та порівняння. Метод прогнозування, експериментального проектування використовуються в розробці проектних пропозицій модернізації планувальної структури військових містечок. Отже, розробка теоретичних принципів модернізації $\epsilon$ основою для проектних пропозицій осучаснення існуючих військових містечок України, а основні положення, висновки та результати наукової роботи використанні в проектуванні.

\section{2. Актуальність теми}

Питання безпеки країн відноситься до числа давніх, в той же час, завжди актуальних проблем. Зважаючи на останні події в геополітичному просторі України 2014-2018 року, питанням цілісності та національної безпеки надається велике значення. Існує потреба в модернізації та осучасненні військових територіальних об'єктів, зокрема військових містечок, які є однією з складових обороноздатності країни та виконують стратегічні функції. Це відносить проблему пошуку ефективних способів та принципів осучаснення архітектурно-планувальної структури, системи культурно-побутового обслуговування та інфраструктури військових містечок до сучасних та найактуальніших завдань, які потребують першочергового вирішення і визначаються програмами державного розвитку, як перспективні напрямки. Сучасні соціокультурні потреби жителів військових містечок диктують необхідність розробки нових підходів, принципів та методів модернізації житлових територій військових містечок. Пошук ефективних шляхів удосконалення житлового середовища військовослужбовців засобами містобудування та архітектури відноситься до сучасних проблем. 
Напрям дослідження модернізації військових містечок пов'язаний 3 державними програмами та стратегіями. Основними з них є «Стратегія воєнної безпеки», «Стратегія національної безпеки» та «Державна програма розвитку Збройних Сил України» [4; 7]. Положення щодо реформування та розвитку Збройних Сил України викладені в плані заходів Міністерства оборони України з виконання «Програми діяльності Кабінету Міністрів України» та «Стратегії сталого розвитку України - 2020 року» від 12 січня 2015 року № 5/2015 [4]. Дана концепція передбачає розвиток військових містечок, формування на їх основі системи автономних військових баз з необхідною інфраструктурою для розташування військових частин із фондом службового житла, соціально-побутовою інфраструктурою для військовослужбовців та членів їх сімей [4; 7]. Державна програма розвитку Збройних Сил України на період до 2020 року передбачає: будівництво та відновлення казармено-житлового фонду, їдалень, інженерних мереж; реконструкція та капітальний ремонт військових об'єктів із впровадженням сучасних технологій із швидкозбірних конструкцій; розквартирування військових частин.

Наказ Міністерства Оборони України від 30.11.2011 року № 737 «Про затвердження Інструкції про організацію забезпечення військовослужбовців Збройних Сил України та членів їх сімей жилими приміщеннями». Постанова Кабінету Міністрів України від 03.08.2006 року № 1081 «Про затвердження Порядку забезпечення військовослужбовців та членів їх сімей житловими приміщеннями«, Постанова Кабінету Міністрів України від 2 вересня 2015 року № 728 «Деякі питання забезпечення житлом військовослужбовців та інших громадян», Рішення Ради національної безпеки і оборони України від 29 грудня 2016 року «Про Державну програму розвитку Збройних Сил України на період до 2020 року» свідчать про актуальність теми дослідження та необхідність розробки сучасних підходів вирішення проблематики забезпечення військовослужбовців та членів їх сімей житлом та модернізації житлових територій військових містечок.

\section{3. Сучасний стан наукових досліджень}

Протягом ХХ століття, групою дослідників було розроблено нормативну документацію «Планировка и застройка военных городков»: Ю. Зайцев, В. Башков, Г. Усенко, В. Звєрьков, А. Соков, А. Харкевич, 
С. Корягін $[8,9]$. Над розробкою відомчих будівельних норм «Загальновійськові споруди» працювали науковці, архітектори, проектувальники: Е. Андронова, П. Афонін, В. Башаков, Ю. Зайцев, А. Козаков, І. Кончева, С. Корягин, Г. Лутошкін, Г. Маленкін, С. Пекарская, Л. Подолян, С. Топорков, Г. Усенко, А. Хрюкін, В. Чернова Б. Шиляєв [8]. Кожен розділ вищезазначеного документу присвячений певному типу будівель військового призначення, до яких відносяться: казарми, об'єкти громадського харчування, клуби, будівлі медичних пунктів, адміністративні службові будівлі, споруди зони парку техніки, будівлі побутового обслуговування, складські споруди та учбові заклади військових частин.

На початку XXI ст. дослідження, що стосуються проблематики військових територіальних об'єктів висвітлюються в роботах: М. Буніна, Ю. Затикіна, М. Максименко, В. Мухіна [2; 5; 6]. В. І. Мухін спільно з М. А. Буніним працювали над розробкою принципів архітектурно-планувальної організації територій спеціального призначення. Питання організації системи культурно-побутового обслуговування військових містечок висвітлює Максименко О. О., в роботах автора докладно проаналізовано архітектурно-планувальна організація центрів обслуговування військових містечок, визначені принципи їх формування з врахуванням соціальних та економічних факторів [5]. Вагомий внесок у розробку методики осучаснення міських територій зробили: М. В. Биваліна, І. І. Гонгало, В. Ф. Касьянов, О. Ф. Осипов, А. М. Плешкановська, М. В. Сисойлов, В. К. Соколов, А. В. Степанюк $[1 ; 2 ; 3]$.

Огляд наукових робіт, різнобічних актуальних гіпотез мають значення для розробки функціональної та архітектурно-планувальної структури військових об'єктів та їх раціональної організації території. При всій широті розгляду наукових аспектів, в роботах вищезазначених вчених не розглянуті, зокрема, питання осучаснення вітчизняних існуючих військових містечок, які розташовані в малих містах України. Не вирішені проблеми удосконалення архітектурно-планувальної, функціональної структури, системи культурно-побутового обслуговування та об'єктів соціальної сфери військових містечок. Існує потреба в дослідженні окреслених питань та містобудівних аспектів знаходження оптимальних рішень для осучаснення вітчизняних військових містечок. Важливо, що проблема модернізації архітектурно-плану- 
вальної структури військових містечок потребує поглибленого аналізу праць низки науковців, що вивчали загальні питання знаходження раціональних підходів до реконструкції міст, міських територій, житлових районів.

Результати наукових досліджень, що пов'язані з військовими об'єктами широко не викладені для загального користування, що є об'єктивним та логічним з міркувань безпеки. Проте, питання архітектурно-планувальної та функціональної організації, реконструкції та осучаснення житлових та громадських територій військових форм територіальної організації все ж залишаються актуальними питаннями і не суперечать проблемам безпеки.

\section{4. Недоліки житлових територій військових містечок}

Основні недоліки військових містечок можна поділити на: містобудівні, функціональні, середовищні та об’єктні. До містобудівних недоліків можна віднести: нефукціональність планувальних рішень військових містечок та нераціональне використання територій. Аналіз архітектурного середовища дозволяє визначити рівень амортизації житлового фонду військових містечок, тому очевидною є необхідність проведення комплексу заходів модернізації елементів містобудівного та архітектурного середовища. В процесі модернізації житлових територій необхідне вирішення ряду питань: соціальних - забезпечення населення комплексом установ та підприємств культурно-побутового обслуговування; санітарно-гігієнічних - забезпечення належного санітарного стану території, нормативної інсоляції території і будинків, зниження рівня шуму, які перевищують нормативні показники, зменшення санітарно-захисних зон за умови спеціальних заходів, протипожежних та цивільної оборони; інженерно-технічних - реконструкції транспортної та інженерної інфраструктури; естетичних $[11 ; 12 ; 13]$.

Військові містечка, які розташовані в малих містах мають функціональну структуру, яка не відповідає сучасним потребам. Відомо, що особливості функціонального зонування, в значній мірі, залежать від типологічної групи військових містечок, розміри території функціональних зон залежать від соціально-демографічних умов. Відповідно планування військових містечок визначається, як формування поліфункціональної структури. Аналіз існуючого стану військових містечок України свідчить про недостатній розвиток соціальної та культур- 
но-побутової інфраструктури. Несформовані громадські території та забудова, які призначені для забезпечення потреб військовослужбовців та членів їх сімей.

Однією з основних проблем сучасних військових містечок $є$ недостатнє житлове забезпечення військовослужбовців. Ця проблема набула значних масштабів, станом на 01.01.2017 р. в черзі на житло перебувають понад 44 тисячі сімей військовослужбовців [4]. Існує потреба збільшення житлового фонду та норми проживання на одну людину. Основний документ, що підтверджує дану необхідність $є$ Наказ Міністерства оборони України від 03.07.2013 № 448 «Положення про організацію квартирно-експлуатаційного забезпечення Збройних Сил України» [4]. Організація квартирно-експлуатаційного забезпечення Збройних Сил України - це комплекс заходів, спрямованих на безпечну експлуатацію, утримання казармено-житлового фонду, об'єктів соціально-культурного призначення, комунальних споруд та інженерних мереж військових містечок, забезпечення військових частин квартирним майном. Загальновійськове планування, що включає в себе комплексне проектування військових містечок і всіх елементів їх інфраструктури - будівель і споруд, що забезпечують повсякденний побут, бойове навчання, зберігання та експлуатацію військової техніки [7].

Найпростіша типова житлова забудова, яка є застарілою і не відповідає сучасним функціональним та естетичним потребам населення, існуючі багатоквартирні будинки є вітхими та застарілими. Особливо незадовільний стан мають будівлі казарм, їх фізичний та моральний знос не відповідає задоволенню сучасних потреб. Зазначені недоліки, дають підстави для покращенням умов проживання шляхом реконструкції та модернізації існуючих будівель. Недоліки архітектурного середовища житлової зони виражається також в занедбаних, неорганізованих прибудинкових територіях з низьким рівнем благоустрою та озеленення. Разом з тим, недостатньо розвинені спортивні та рекреаційні зони. На території військових містечок недостатня кількість відкритих майданчики для оздоровчих та спортивних комплексів, разом 3 тим, існує необхідність створення місць рекреації [12; 13].

Архітектурне середовище житлових зон військових містечок справляє похмуре та неестетичне враження на жителів. Тому, існує необхідність гармонізації середовища та підвищення естетичних якостей 
військових містечок шляхом використання архітектурних та композиційних прийомів, що відповідають сучасним стильовим тенденціям. Гармонізації середовища об'ємно-просторової та архітектурно-планувальної структур військових містечок набуває особливого значення в умовах сталого розвитку [13].

На основі аналізу вітчизняного та закордонного досвіду територіальної організації військових об' єктів, що складаються з цивільної та військової частини, були визначені особливості містобудівних рішень та їх проблематика. Вивчення характеристик планування вищезазначених об'єктів дозволило виявити основні причини, що визначили необхідність та доцільність їх модернізації, а саме: невідповідність сформованої планувальної структури діючим будівельним нормам та соціально-культурним потребам, недостатня ефективність використання територій; дефіцит забезпеченості військовослужбовців житлом; низький рівень соціального та культурно-побутового обслуговування; відсутність рекреаційних зон; моральний і фізичний знос забудови.

\section{5. Напрямки модернізації житлових територій військових містечок}

Як свідчить аналіз, проблема осучаснення архітектурно-планувальної структури житлових територій військових містечок на сьогодні не отримала глибокого дослідження в наукових джерелах. Ще й досі існує потреба розробки сучасних підходів у вивченні даної тематики. Теоретичні питання модернізації охоплюють широке коло проблем. Загальні питання реконструкції та модернізації міст та міських територій висвітлені в роботах: А. М. Плешкановської, М. В. Сисойлова, В. К. Соколова, М. В. Биваліна, В. Ф. Касьянова, І. І. Гонгало, О. Ф. Осипова, А. В. Степанюка $[1 ; 2 ; 10 ; 11]$. Військове містечко є містобудівним об'єктом, тому найбільш грунтовними для даного дослідження є наукові розробки А. М. Плешкановської. В наукових працях автора викладені методи та прийоми реконструкції, розглядається функціонально-планувальна оптимізація міських територій, які зокрема стосуються і наших проблем. Докладно висвітлені основні напрямки реконструкції житлової забудови, що є корисними для розробки методики модернізації вітчизняних військових містечок. Низка сучасних науковців сконцентровані, в своїх працях, на дослідження певної проблематики пов'язаної з функціональним зонуванням, пла- 
нуванням, забудовою, організацією архітектурних комплексів та окремих будівель. Для даного дослідження є цінними наукові праці та доробки сучасних вчених, які діднімають основні актуальні проблеми реконструкції та модернізації [10; 11].

Існуючі недоліки архітектурного та містобудівного середовища військових містечок диктують необхідність розробки сучасних принципів та методів модернізації. Пошук ефективних шляхів осучаснення архітектурно-планувальної та функціональної структури, системи культурно-побутового обслуговування та інфраструктури військових містечок відноситься до сучасних завдань, які потребують більш детального дослідження та розробки сучасних підходів до вирішення проблематики їх модернізації.

Державними цільовими програмами та стратегіями розвитку передбачається ряд заходів спрямованих на будівництво та відновлення казармено-житлового фонду, їдалень, інженерних мереж; розквартирування (розміщення) військових частин у районах виконання завдань; відновлення та нарощування аеродромної мережі; будівництво, реконструкція та капітальний ремонт, насамперед у східному та південному регіонах; будівництво та реконструкція військових об'єктів із впровадженням сучасних технологій із швидкозбірних конструкцій; забезпечення підрозділів сучасними малогабаритними, малопомітними польовими модулями, захищеними спорудами та іншими об'єктами польової інфраструктури; забезпечення потреб у розквартируванні особового складу та частково оновлена інфраструктура військових містечок та інших військових територіальних об'єктів [5].

Будівництво житлових комплексів для контрактників здійснюватиметься здебільшого на територіях існуючих військових містечок майже по всій території України в 21 області. Планується побудувати 184 житлових комплексів для військовослужбовців Збройних Сил України. Таке рішення $є$ оптимальним з точки зору збереження та максимально ефективного використання комунікацій і мережі, елементи інженерної інфраструктури [5].

Вивчений досвід став основою для виявлення принципів модернізації військових територіальних об'єктів, а саме: територіального розвитку, інтеграції, адаптації та трансформації. Вони в своїй структурі поділяються на три рівні: архітектурно-планувальний, функціональний та об’єктний. Завдяки диференціації містобудівного середовища 
визначається раціональний підхід до вирішення проблематики осучаснення необхідних структурних елементів в залежності від потреб. Зміст принципу територіального розвитку військових містечок полягає в можливості розширення військових територіальних об'єктів за рахунок вільних прилеглих територій. Даний принцип реалізується за рахунок включення та освоєння незабудованих територій для розквартирування та забезпечення соціальних та культурно-побутових потреб населення, що працює та проживає у військовому містечку. Основною метою є створення нових осередків військового, житлового та громадського будівництва.

Принцип інтеграції полягає у доповненні елементів містобудування, до існуючої архітектурно-планувальної структури, додаються нові утворення, що забезпечують створення нових об'єктів, сучасних складових містобудівного простору. Принцип інтеграції на об'єктному рівні передбачає включення необхідних будівель та споруд, закладів та об'єктів освіти, спорту, торгівлі, громадського харчування та медицини, що забезпечується вибірковим будівництвом, в умовах обмеженого територіального розвитку військового містечка. Відповідність структурних елементів містобудівного середовища сучасним будівельним нормам та соціально-культурним потребам визначаються принципом адаптації. Під час модернізації необхідно перепланувати простори під новий зміст надавши архітектурному середовищу новий імпульс для розвитку. Принцип трансформації та адаптації заключається у перетворенні територій, зон та будівель 3 певних функціональним призначенням під інше цільове використання [7].

Зазначенні принципи модернізації військових містечок поєднують планувальні, функціональні та об'єктні напрямки сучасного розвитку, шляхи їх реалізації зумовлені застосуванням методів та прийомів осучаснення військових територіальних об'єктів. Для реалізації принципів застосовуються методи: екстенсивного розвитку, ущільнення забудови, ускладнення архітектурного середовища, перепланування, реорганізація, пристосування, функціональної відповідності та оновлення. Нами виявлені відповідні прийоми розвитку архітектурного простору: освоєння нових територій, вибіркове будівництво, надбудова, прибудова, зміна функціонального призначення території, реорганізація. Принципи, методи та прийоми модернізації військових містечок визначені у відповідності до існуючої проблематики сучасних 


\section{Morozik Alina, Vasylenko Lyudmila}

військових територіальних об'єктів України та з врахуванням недоліків архітектурного середовища. Різноплановість містобудівних ситуацій, особливості архітектурно-планувальних та об'ємно-просторових рішень визначили необхідність комплексного використання методів та прийомів. Варіативність принципів дозволять визначати доцільний напрям осучаснення для конкретного містобудівного об'єкту з врахуванням їх особливостей.

Представлений в теорії містобудування принцип територіального розширення $\epsilon$ прикладом екстенсивного розвитку військових містечок і початковим рівнем модернізації. Його зміст полягає в можливості розширення військових територіальних об'єктів за рахунок вільних прилеглих територій. Осучаснення військових містечок має низку можливих шляхів поліпшення, одним із яких може бути реалізація за рахунок включення та освоєння незабудованих територій для розквартирування та забезпечення соціальних та культурно-побутових потреб населення. Основною метою є створення нових осередків житлового та громадського будівництва $[10 ; 11]$.

Одним з найпоширеніших базових принципів в теорії містобудування є принцип функціональної інтеграції (функціонального насичення). Наступні принципи осучаснення військових містечок $€$ прикладами інтенсивного розвитку, де є можливості трансформації показників від кількісних до якісних. Визначена у відомчих нормативних документах функціональна структура відкритих військових містечок України має сталу базову модель зонування [7]. Спираючись на проведене нами дослідження, існує можливість насичення функціонального зонування за рахунок інтеграції нових функціональних зон в існуючу структуру, що сприятиме покращенню комфортних умов соціального та культурно-побутового обслуговування, задоволення соціально-культурних потреб мешканців. В осучасненні військових містечок України виникає необхідність розширення функціональної структури за рахунок включення додаткових зон: спортивно-рекреаційної, науково-просвітницької, навчально-тренувальної, адміністративної та медично-реабілітаційної [5].

Інтеграція на об'єктному рівні передбачає включення додаткових будівель та споруд. Інтегрування закладів та об'єктів освіти, спорту, торгівлі, громадського харчування та медицини забезпечується вибірковим будівництвом, в умовах неможливого територіального розвитку 
архітектурно-планувальної та функціональної структури військового містечка. Принцип об'єктної інтеграції є одним 3 найефективніших принципів модернізації військових містечок України, оскільки він може бути застосований в умовах забудови, що склалася без радикальних змін архітектурно-планувальної та інженерно-транспортної структури. Локальне доповнення до вже існуючої забудови є раціональною можливістю осучаснення в умовах обмежених територіальних ресурсів військового містечка, де визначені вузькі межі модернізації архітектурного простору [10].

Зміст принципу функціональної трансформації, який полягає у перетворенні територій з певним функціональним призначенням на інше цільове використання. Під час модернізації необхідно перепланувати простори під новий зміст надавши архітектурному середовищу новий імпульс для розвитку. Завдання модернізації полягає у створенні по можливості гнучкої планувальної структури для зниження необхідності радикальних трансформацій під час подальшого осучаснення містобудівного та архітектурного середовища $[8,9]$. Аналіз допомагає визначити території з функціональним призначенням, які використовуються не ефективно 3 точки зору параметрів щільності забудов. Даний принцип дозволяє переорганізувати існуючу функціональну структуру, що дозволяє раціонально використати містобудівний простір військового містечка і забезпечує його осучаснення.

Більшість об'єктів військової інфраструктури внаслідок змін соціальної політичної та економічної ситуації у країні, втратили своє початкове призначення. Конструктивні схеми, задовільний технічний стан будівель (казарм, штабів, їдалень, медичних закладів тощо) та вдале розташування на території колишніх військових містечок з розвинутою інфраструктурою дозволяє розглядати їх як перспективні об'єкти 3 метою створення фондів житла різних категорій, у тому числі і соціального. Реконструкція цих об'єктів супроводжується модернізацією інженерного обладнання, утепленням огороджувальних конструкцій та благоустроєм прибудинкової території.

Принципи архітектурно-планувальної інтеграції, трансформації та адаптації включають в себе більший спектр можливих методів та прийомів модернізації військових містечок і $є$ більш широким поняттям, що вміщує в себе функціональну структуру та транспортно-інженерну мережу [10]. Принцип архітектурно-планувального доповнення 


\section{Morozik Alina, Vasylenko Lyudmila}

полягає у формуванні нових архітектурно-планувальних утворень: житлових кварталів та громадських осередків, центрів (територій). До існуючої архітектурно-планувальної структури доповнюються нові містобудівні утворення, що забезпечує створення нових об' єктів, сучасних елементів містобудівного простору та забезпечує модернізацію військового містечка. Архітектурно-планувальна трансформація полягає в перетворенні територій під нові архітектурно-планувальні утворення. Перепланування та створення нових структур, використання територій для розвитку містобудівного та архітектурно простору за рахунок реорганізації. Території, що використовуються малоефективно потребують перепланування з можливістю організації сучасного простору. Принцип архітектурно-планувальної та функціональної адаптації полягає в перетворенні середовища зі збереженням елементів вже сформованої системи архітектурно-планувальної або функціональної структури. Надає можливість підпорядкувати містобудівне та архітектурне середовище найбільш ефективними засобами за рахунок використання існуючих елементів та доповнення необхідними [11]. Завдання модернізації на містобудівному рівні $є$ раціональне використання земель та територій для містобудівних потреб, підвищення ефективності забудови та іншого використання земельних ділянок.

Прийоми модернізації способи здійснення осучаснення середовища проживання військовослужбовців. Ущільнення забудови (прибудова, надбудова). В умовах існуючої забудови основними 3 можливих способів реалізації осучаснення архітектурного середовища на містобудівному рівні включаючи архітектурно-планувальну та функціональну структуру $є$ таки прийоми модернізації як прибудова та надбудова. Раціональним і економічно ефективним є підвищення щільності забудови шляхом надбудови і прибудови, влаштування багатоповерхових вставок між будинками і зведення окремих житлових корпусів, створення об'єктів інфраструктури, більш продуктивного використання підземного простору [3; 10; 11].

Комплексне вирішення модернізації квартальної забудови дозволяє створити комфортні умови проживання, що відповідають сучасним вимогам міського середовища, врахувати вимоги до формування соціальної сфери, необхідної для нормальної життєдіяльності громадян. Модернізація житлової забудови не повинна супроводжуватися 
погіршенням інсоляції та аерації i, як наслідок, має бути спрямована на поліпшення мікроклімату житлової забудови, підвищення комфортності проживання та оздоровлення умов проживання населення [12]. Ускладнення архітектурно-планувальної та функціональної структури. (насичення, інтеграція, додавання планувальних та функціональних елементів, вибіркове будівництво). Ускладнення та насичення функціонального зонування. Додавання нових функціональних зон для забезпечення покращення соціального та культурно-побутового обслуговування.

Локальна модернізація передбачає застосування певного принципу на окремому рівні містобудівного середовища. Комплексна модернізація передбачає застосування сукупності принципів: територіального розвитку, функціональної інтеграції, трансформації та адаптації, принципи архітектурно-планувального доповнення (інтеграції) та трансформації, а також принципу інтеграції для найповнішого осучаснення існуючих військових містечок України. Принципи модернізації військових містечок визначені у відповідності до існуючої проблематики сучасних військових територіальних об'єктів України та $з$ врахуванням недоліків архітектурного та містобудівного середовища. Модернізація військових містечок спрямована на осучаснення містобудівного середовища та його елементів, що обумовлено недоліками планування та забудови. Різноплановість містобудівних ситуацій, особливості архітектурно-планувальних та об'ємно-просторових рішень визначили необхідність створення принципів модернізації, які в поєднанні можуть надати ефективніший результат. Комбінації використання принципів дозволять визначати напрям осучаснення в конкретному випадку, знаходячи раціональні рішення, методи та прийоми модернізації.

\section{6. Впровадження принципів модернізації військових містечок}

Теоретичні принципи модернізації були апробовані в експериментальному проектуванні та при розрозробці містобудівної документації. Основні результати досліджень модернізації житлової частини військових містечок були використані при виконанні дипломної роботи на тему: «Детальний план території військового містечка відкритого типу в м. Чугуєві». Проектними рішеннями передбачено розвиток військового містечка за рахунок освоєння вільних територій та осучаснення 


\section{Morozik Alina, Vasylenko Lyudmila}

існуючої планувальної і функціональної структури. Запроектовано житлові квартали з об’єктами щоденного (первинного) культурно-побутового обслуговування, а також створення військової частини, що відповідає сучасним потребам.

Також, одним із завданням було поєднання існуючої забудови 3 проектною та удосконалення архітектурного середовища в цілому. Тому, застосовані принципи модернізації для осучаснення існуючого планування та забудови вищезазначеного військового містечка, а саме: принцип функціональної інтеграції та трансформації, а також об'єктної (локальної) інтеграції. Одним з найпоширеніших принципів в теорії містобудування $є$ принцип функціональної інтеграції.

Також, в проекті визначений напрямки функціонального переосвоєння територій військового містечка. Аналіз допомагає визначити території 3 функціональним призначенням, які використовуються неефективно 3 точки зору параметрів щільності забудов, кількості постійно перебуваючого населення та відвідування. Даний принцип дозволяє переорганізувати існуючу функціональну структуру, що дозволяє раціонально використати містобудівний простір військового містечка і забезпечує його осучаснення. Спираючись на проведене нами дослідження, існує можливість насичення функціонального зонування за рахунок додавання нових функціональних зон в існуючу функціональну структуру, що сприяють покращенню умов соціального та культурно-побутового обслуговування для задоволення соціально-культурних потреб жителів [8].

Для локального осучаснення існуючого планування військового містечка був застосований принцип інтеграції, який на об'єктному рівні передбачає включення додаткових будівель та споруд, закладів та об'єктів, а саме: освіти, спорту, торгівлі, громадського харчування та медицини, які забезпечується вибірковим будівництвом, в умовах неможливого територіального розвитку архітектурно-планувальної та функціональної структури військового містечка. Локальне доповнення до вже існуючої забудови $є$ раціональною можливість осучаснення в умовах обмежених територіальних ресурсів військового містечка, де визначені незначні можливості модернізації архітектурного простору. Принцип об'єктної інтеграції є супутнім принципом до вищезазначених, оскільки є доповненням в більш широких процесах модернізації [13]. 
Разом з принципами модернізації військових містечок, також були застосовані планувальні принципи міського середовища: розділення потоків транспорту та пішоходів; створення озеленених просторів, які створюють єдину структуру; організація розвиненої системи культурно-побутового обслуговування. В існуючій житловій частині були розміщені заклади культурно-побутового обслуговування, передбачено покращення транспортної інфраструктури та благоустрій озеленених територій. Проектна сельбищна зона представлена житловими квартали багатоквартирної забудови, які сформовані з секційних будинків середньої поверховості (3-5 поверхи). Центр військового містечка складається 3 громадських будівель. Всі функціональні зони військових містечок поєднуються пішохідними зв'язками з врахуванням дисперсії пішоходів. Основний пішохідний бульвар є комунікаційним сполученням, що поєднує громадський центр, житлові квартали та паркову зону. Ландшафтно-рекреаційна зона запроектована 3 врахуванням навантаження на ландшафт та враховує розподілення потоків пішоходів. Планувальна організація військової частини виконана у відповідності до відомчих планувальних норм «Планування та забудова військових містечок». В цілому планування військового містечка регулярне з чітко визначеними планувальними осями.

Наступним прикладом модернізації військових територіальних об'єктів є військове містечко розташоване в місті Старокостянтинів Хмельницької області. Згідно проекту генерального плану м. Старокостянтинів, ділянка проектування передбачена під квартал багатоквартирної багатоповерхової житлової забудови з об'єктами громадського обслуговування. Ділянка, що проектується, знаходиться в північно-західному напрямку від центру міста Старокостянтинів в межах населеного пункту на території військового містнчка, що належать Міністерству Оборони України. На ділянці проектування частково розташовуються існуючі будівлі військової частини, які мають високих рівень амортизації. Натомість перенесення їх заплановане на територію військової частини в рамках іiї реконструкції та модернізації. Основні фактори, які впливають на проектну архітектурно-планувальну та об'ємно-просторову організацію: особливості планування існуючої забудови міста; планувальні обмеження; матеріали історико-архітектурного плану, врахування наявного територіального розподілу території; забезпечення санітарно-гігієнічних, протипожежних та інших 
містобудівних умов. В осучасненні військового містечка в м. Старокостянтинові були використані принципи архітектурно-планувальної трансформації та адаптації. Для забезпечення соціальних потреб застосовується принцип функціональної та об’єктної інтеграції [12].

Також, при розробці детального плану території житлової частини військового містечка були враховані: взаємозв'язки планувальної структури військового містечка 3 існуючою планувальною структурою; забезпечення проектного кварталу об'єктами соціального, громадського, побутового та культурного обслуговування та нормативною кількістю автостоянок. На території площею біля 15 га, проектом передбачається розміщення секційних середньоповерхових житлових багатоквартирних будинків, що формують компактну планувальну структуру кварталу військового містечка. Біля будинків передбачено розміщення дитячих майданчиків, облаштованих місць тихого відпочинку, майданчиків для занять фізкультурою, господарських майданчиків та гостьових стоянок. Проектом модернізації військового містечка намічається будівництво житлової забудови 3 закладами повсякденного обслуговування. 3 метою забезпечення оптимальних умов перебування населення на території цивільної частині військового містечка в проекті передбачено площі озеленених територій загального користування житлових районів згідно нормативних показників 3 подальшою організацією благоустрою [3; 12; 13$]$.

Крім апробації результатів дослідження в експериментальному проектуванні, виконані впровадження основних принципів методів та приймів модернізації цивільної частини військових містечок України відкритого типу при виконанні містобудівної документації, проектів генеральних планів та пану зонування. При розробці генерального плану м. Гайсин впроваджені принципи модернізації, а саме: функціональної інтеграції та трансформації цивільної частини військового містечка на прикладі м. Гайсин з метою функціонального насичення, ефективного розвитку житлової зони та удосконалення територій спеціального призначення. Комплексний аналіз архітектурно-планувальної та функціональної структури військових містечок та територій спеціального призначення дозволяє розробити наукові пропозиції їх осучаснення та розвитку з урахуванням містобудівних, екологічних, соціально-демографічних та економічних вимог при розроблені містобудівної документації. 
Дослідження планування та забудови військового містечка відкритого типу диктують необхідність застосування принципів та методів ïx модернізації. Визначені актуальні напрямки осучаснення функціональної структури та системи культурно-побутового обслуговування. На прикладі міста Чортків 3 метою функціонального насичення та ефективного використання територій військового містечка впроваджені принципи модернізації, а саме: функціональної та архітектурно-планувальної адаптації житлової частини військового містечка. Різноплановий підхід з можливими варіаціями осучаснення від локальної до комплексної модернізації визначає адаптивні можливості запропонованих компонентів осучаснення. Апробація принципів модернізації житлових територій військових містечок визначає можливість подальшого застосування принципів методів та прийомів на подальших стадіях проектування (детальний план території, робоча документація та проекти благоустрою прибудинкових територій).

\section{7. Висновки}

Першочергова потреба вирішення проблематики модернізації житлових територій військових містечок, удосконалення середовища проживання військовослужбовців та забезпечення їх житлом, розквартирування є актуальними питаннями, про що свідчать державні програми спрямовані на розвиток військових об'єктів. Принципи модернізації військових містечок визначені у відповідності до існуючої проблематики сучасних військових територіальних об'єктів України та $з$ врахуванням недоліків архітектурного та містобудівного середовища. Варіативність використання принципів дозволять визначати напрям осучаснення в конкретному випадку знаходячи раціональні рішення, методи та прийоми. Розроблені пропозиції щодо модернізації військових містечок з урахуванням особливостей діючої законодавчої та нормативної баз. Експериментально та теоретично підтверджена ефективність основних принципів модернізації військових містечок: територіального розвитку, інтеграції, адаптації та трансформації. Здійсненні проектні впровадження принципів, методів та прийомів модернізації житлових територій військових містечок України відкритого типу при виконанні містобудівної документації проектів генеральних планів та плану зонування. Крім того, розроблені теоретичні та методичні основи осучаснення військових містечок були застосо- 
вані у дипломному та курсовому проектуванні для студентів п'ятого та шостого курсів $з$ напрямку підготовки «містобудування» та «архітектура». Вищезазначені роботи підтверджують результативність виявлених підходів осучаснення архітектурно-планувальної структури цивільної частини відкритих військових містечок.

\section{Список літератури:}

1. Биваліна М. В. Проблеми та методи модернізації районів масової житлової забудови 1960 - 1970-х років (на прикладі м. Києва) : Автореф. дис... канд. техн. наук / М. В. Биваліна; Київ. нац. ун-т буд-ва і архіт. - К.: КНУБА, 2003. $-19 \mathrm{c}$.

2. Дьомін М. М. Проблеми та методи модернізації районів масової житлової забудови 1960-1970-х років (на прикладі м. Києва) / М. М. Дьомін, М. В. Биваліна // Містобудування та територіальне планування: Наук.-техн. збірник / Відпов. ред. М. М. Осєтрін. - К. : КНУБА, 2005. - Вип. 21. - С. 67-75.

3. Волкова Т. Ф. реабилитация городской жилой среды. Социальноградостроительный аспект: учеб. пособие / Т. Ф. Волкова. - Пенза: ПГУАС, 2014. $-116 \mathrm{c}$.

4. Закон України: «Про державні цільові програми» // Відомості Верховної Ради України (ВВР). - 2004, N 25. - 352 с.

5. Максименко О. А., Архитектурно-планировочная организация центров обслуживания военных городков: автореферат дис. ... кандидата архитектуры: 05.23.21 / Максименко Ольга Александровна, Москва, 2013. - 26 с.

6. Мухин В. И. Социально-демографические основы совершенствования организации жилых территорий постоянного населения военных городков / В. И. Мухин. - Л., ЛВВИСКУ, 1985. - 355 с.

7. Наказ Міністра оборони України «Про затвердження Положення про організацію квартирно-експлуатаційного забезпечення Збройних Сил України». - 2011, № 215.

8. Планировка и застройка военных городков // Нормы проектирования: ВСН 34-94. М.: МО РФ, 1994. - 102 c.

9. Планировка и застройка военных городков: Нормы проектирования. BCH 34-89. / MO СССР М., 1989. - 88 c.

10. Плешкановська А. М. Методологія комплексної реконструкції міста : автореф. дис. ... д-ра техн. наук / А. М. Плешкановська; К.: КНУБА. - Київ, 2013. $-40 \mathrm{c}$.

11. Плешкановська А. М. Проблеми реновації забудови міських територій / А. М. Плешкановська // Містобудування та територіальне планування: Наук.-техн. збірник / Відпов. ред. М. М. Осєтрін. - К. : КНУБА, 2006. Вип. 25. - С. 183-191.

12. Методика реконструкции городов / ЦНИИП градостроительства. - М.: Стройиздат, 1975. - 197 с.

13. Шепелев Н. П. Реконструкция городской застройки: Учеб. для строит. спец. вузов. / Н. П. Шепелев, М. С. Шумилов - М.: Высш. шк., 2000. -271 с. 


\section{Modernization housing territories of Ukraine's military cities. Background...}

\section{References:}

1. Byvalina M. V. Problems and methods of modernization of areas of mass housing development of the 1960s - 1970s (for example, Kyiv) : Author's abstract. Kiev.: KNUBA, 2003. -19 p.

2. Djomin M. M. Problems and methods of modernization of areas of mass housing development of the 1960-1970s (for example, Kyiv). Urban Planning and Territorial Planning: Scientific Collection (electronic journal). Kiev.: KNUBA, 2005. - Vol. 21. - pp. 67-75.

3. Volkova T. F. Rehabilitation of urban living environment. Social-townplanning aspect. Penza, 2014. -116 p.

4. Law of Ukraine: "On State Target Programs". - 2004, n. 25. - 352 p.

5. Maksymenko O. A. Architectural and planning organization of service centers for military towns. 2013. $-26 \mathrm{p}$.

6. Mukhin V. I. Socio-demographic fundamentals of improving the organization of residential areas of the permanent population of military towns. LVVISKU.1985. $-355 \mathrm{p}$.

7. Order of the Minister of Defense of Ukraine "On Approval of the Regulation on the Organization of Apartment Maintenance of the Armed Forces of Ukraine". 2011, № 215.

8. Planning and building of military camps. VSN 34-94. Moscow: Ministry of Defense of the Russian Federation, 1994. - 102 p.

9. Planning and building of military camps. Design standards. VSN 34-89. I USSR Moscow: 1989. $-88 \mathrm{p}$.

10. Pleshkanovsjka A. M. Methodology of the complex reconstruction of the city, Kiev.: KNUBA, 2013. -40 p.

11. Pleshkanovsjka A. M. Problems of renovation of urban areas / Kiev.: KNUBA, 2006. - vol. 25. - 183-191 pp.

12. Methods of urban reconstruction. Central Research Institute of Urban Planning. - Moscow: Stroyizdat. - 1975. - 197 p.

13. Shepelev N. P. Reconstruction of urban development. Moscow.: ext. shock, 2000. $-271 \mathrm{p}$. 